(자 $a>$ u

C entre for

A boriginal

E conomic

$P$ olicy

$\mathbf{R}$ esearch

Discussion Paper

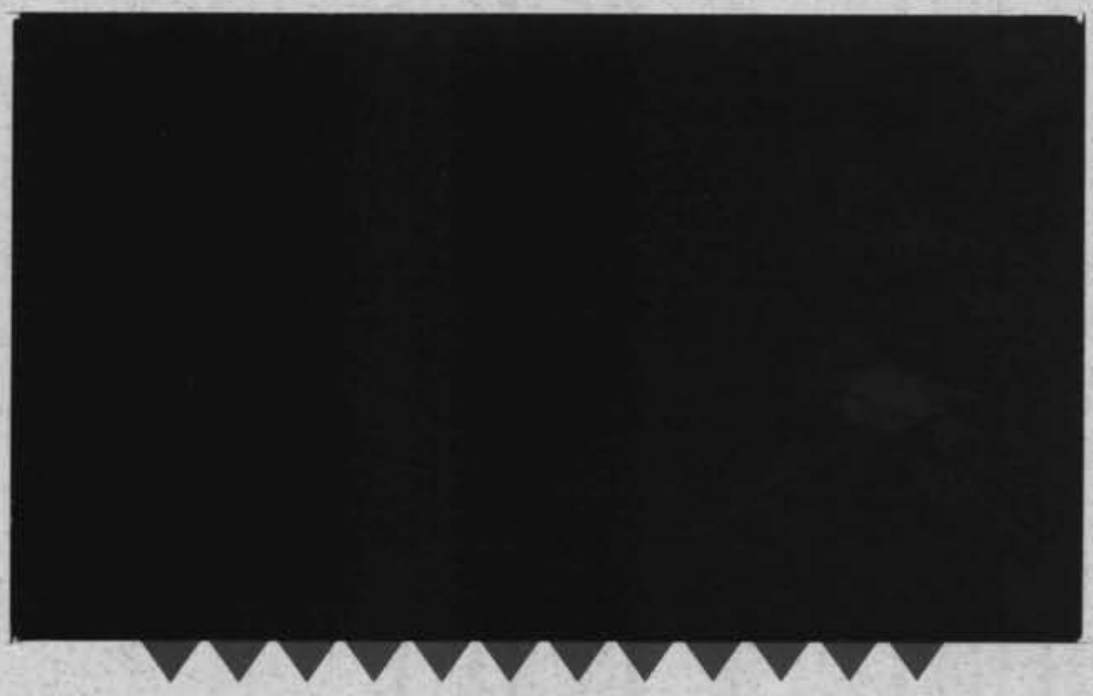




\section{Reconciling public accountability and Aboriginal self-determination/self- management: is ATSIC succeeding?}

\section{W. Sanders}

No.51/1993 


\section{SERIES NOTE}

The Centre for Aboriginal Economic Policy Research (CAEPR) was established in March 1990 under an agreement between the Australian National University and the Commonwealth of Australia (Aboriginal and Torres Strait Islander Commission). CAEPR operates as an independent research unit within the University's Faculty of Arts. CAEPR's principal objectives are to undertake research to:

- investigate the stimulation of Aboriginal and Torres Strait Islander economic development and issues relating to Aboriginal and Torres Strait Islander employment and unemployment;

- identify and analyse the factors affecting Aboriginal and Torres Strait Islander participation in the labour force; and

- assist in the development of government strategies aimed at raising the level of Aboriginal and Torres Strait Islander participation in the labour market.

The Director of the Centre is responsible to the Vice-Chancellor of the Australian National University and receives assistance in formulating the Centre's research agenda from an Advisory Committee consisting of five senior academics nominated by the Vice-Chancellor and four representatives nominated by the Aboriginal and Torres Strait Islander Commission, the Department of Employment, Education and Training and the Department of Social Security.

CAEPR DISCUSSION PAPERS are intended as a forum for the dissemination of refereed papers on research that falls within the CAEPR ambit. These papers are produced for discussion and comment within the research community and Aboriginal affairs policy arena. Many are subsequently published in academic journals. Copies of discussion papers can be purchased from Reply Paid 440, ANUTECH Pty Ltd, Canberra ACT 0200. Ph (06) $2492479 \mathrm{Fax}(06) 2575088$.

As with all CAEPR publications, the views expressed in this DISCUSSION PAPER are those of the author(s) and do not reflect an official CAEPR position.

Jon Altman

Director, CAEPR

Australian National University 


\section{ABSTRACT}

Since the early 1970s Commonwealth Governments have been pursuing policies of self-determination/self-management in relation to Aborigines. In 1987, the Hawke Government announced its intention to establish an Aboriginal and Torres Strait Islander Commission (ATSIC) to further this policy goal. During the debates over ATSIC's formation, the issue of public accountability in the existing administration of Aboriginal affairs came to public prominence. The result was some extensive reworking of the ATSIC proposal, which in 1989 re-emerged with a strengthened emphasis on public accountability. This article traces the events and arguments surrounding ATSIC's formation and then goes on to examine ATSIC in practice. It asks whether ATSIC is succeeding in reconciling the two imperatives of Aboriginal self-determination/self-management and public accountability.

\section{Acknowledgments}

An earlier version of this paper was presented as a seminar at the Australian National University on 18 October 1993. Participants at that seminar provided useful comments and probing questions. I would like to thank Bill Miller, Geoff de Souza, Russell Taylor and Giff Jones of ATSIC for useful discussions. I would also like to thank Diane Smith, Rolf Gerritsen, Nic Peterson and Jon Altman for reading and commenting on drafts of the paper, though the responsibility for the final content is entirely my own. Finally I would like to thank Linda Roach, Krystyna Szokalski and Nicky Lumb for assistance with final layout and editing.

Will Sanders is Research Fellow at the Centre for Aboriginal Economic Policy Research, Faculty of Arts, Australian National University. He is, in that capacity, also coordinator of the Institutions of Aboriginal Australia Strand of the ANU's Reshaping Australian Institutions Project. 

For 20 years now, Australian Commonwealth Governments have been pursuing policies of self-determination and self-management in relation to Aborigines. ${ }^{1}$ At the core of these policies has been the idea that Aborigines themselves should be involved in the decision-making processes that affect their lives. At the regional and local levels this has led to the encouragement and funding of incorporated Aboriginal organisations, both to deliver specific services and to manage general Aboriginal community affairs. There are now over 2,000 incorporated Aboriginal associations Australia-wide, institutionally quite separate from government but predominantly government funded.

At the national level, these policies of self-determination and selfmanagement led to two early experiments in the creation of governmentsponsored Aboriginal representative structures, the National Aboriginal Consultative Committee (NACC) 1973-1977 and the National Aboriginal Conference (NAC) 1977-1985. They also led to the establishment, in 1980, of the Aboriginal Development Commission (ADC), a statutory authority governed by a board of appointed Aborigines with the task of administering a limited range of the more development-oriented programs within the Commonwealth's Aboriginal affairs portfolio.

None of these early institutional experiments at the national level were particularly successful or long lived. The NACC and NAC, while elected by Aborigines, were advisory bodies only. They suffered greatly from the criticism that they did not go far enough in giving decision-making power in Aboriginal affairs to Aborigines (see, for example, Hiatt 1976; Coombs 1984). The ADC, while not coming under so much criticism from this quarter, acquired critics of another sort. By 1984, it was being criticised by a Parliamentary Committee for 'very significant weaknesses' in its grant assessment, administration and monitoring procedures (House of Representatives Standing Committee on Expenditure 1984).

In 1986 and 1987, while casting around for some arrangement to replace the NAC, the Hawke Government settled on the idea of an Aboriginal Commission which would attempt to combine both representative and executive roles and so allay the criticism that decision-making power over Aboriginal affairs policies and programs had never been fully given to Aborigines. The new Commission would combine regional and national assemblies of elected Aborigines with the program administration roles of the Commonwealth Department of Aboriginal Affairs (DAA) and other Aboriginal affairs portfolio bodies, such as the ADC. The idea, although it had clearly been around for some time, seemed to come most directly from Coombs' 1984 review of the NAC and from subsequent consultations with Aboriginal people (see Coombs 1984; O'Donoghue 1986).

Prime Minister Hawke first announced the Government's intention to establish such a Commission in July 1987. A proposal for the body, to be 
known as the Aboriginal and Torres Strait Islander Commission (ATSIC) was first put to Parliament in a statement entitled 'Foundations for the Future' by the Minister for Aboriginal Affairs, Gerry Hand, in December 1987 (Commonwealth Parliamentary Debates, Vol. H of R 158: 3152-61, 10 December 1987). Thereafter followed a period of consultation with Aboriginal people in which Minister Hand and the Secretary of the DAA, Charles Perkins, attended meetings across the country. The reaction from Aboriginal people was not, however, always positive. The ADC's Aboriginal Commissioners, for example, opposed the proposal quite strongly. They were, for their trouble, dismissed and replaced by Minister Hand in May 1988. This provoked the Coalition and the Democrats to combine in the Senate to establish a select committee to examine and report on the ATSIC proposal and the ADC dismissals (Commonwealth Parliamentary Debates, Vol. S 127: 3315-7, 1 June 1988). The existence of this committee then stymied the Government's efforts to proceed with ATSIC until after it had reported late in 1988 (Commonwealth Parliamentary Debates, Vol. H of R 162: 876, 1 September 1988; Vol. S 129: 1825, 2 November 1988; see also Senate Select Committee on the Administration of Aboriginal Affairs 1989).

Meanwhile, in other Parliamentary forums, such as question time and Senate Estimates Committee hearings, members of the Coalition relentlessly questioned the Government over alleged inadequacies in the existing administration of Aboriginal affairs (see for example Commonwealth Parliamentary Debates, Senate Estimates Committees 1031 October 1988: E257-265, E327-401). Charles Perkins was forced to resign as Secretary of the DAA after falling out with Minister Hand over proposed funding of poker machines by the ADC at an Aboriginal club in Canberra. The Opposition even called for a Royal Commission into Aboriginal affairs administration. The Government, however, resisted this call and attempted to push ahead with its ATSIC proposal while also convening a number of more routine administrative inquiries into the existing workings of the DAA and the ADC (Commonwealth Parliamentary Debates, Vol. H of R 163: 2457-67, 7 November 1988).

No less than five such administrative inquiries into the existing administration of Aboriginal affairs were instigated in late 1988 and completed during the early months of 1989 ; one by the Auditor-General, one by the Public Service Commission, two by the Department of Finance and one by a specially-appointed senior public servant (Auditor-General 1989; Public Service Commission 1989; Department of Finance 1989a; Department of Finance 1989b; Department of Prime Minister and Cabinet 1989). The general tenor of the reports of these inquiries was rather critical of the existing administration of Aboriginal affairs. Though specific allegations of individual misconduct were seldom substantiated, general shortcomings in the procedures of both the DAA and the ADC were 
frequently identified. Both the probity and public accountability of the administration of Aboriginal affairs were clearly being called into question and the DAA and the ADC both found themselves increasingly under siege.

The effect of this scrutiny and criticism on the Hawke Government's ATSIC proposal was immediate and obvious. When revised legislation for the Commission was introduced to the Parliament in April 1989, there was a much enhanced emphasis on the public accountability of the new Commission to Parliament through the Minister. When commenting on the reports of the administrative inquiries and introducing the revised ATSIC proposal to the Parliament, Prime Minister Hawke argued that the 'nub of the issue' was 'finding the right balance between the principles of selfmanagement and of overall ministerial responsibility'. He continued:

The Government believes it is possible - indeed, it is vital - to strike a better balance; a balance that both widens and deepens the opportunity for selfmanagement, and establishes a more appropriate means of financial accountability and ministerial oversight. That is precisely what the Government's proposed legislation for the establishment of the Aboriginal and Torres Strait Islander Commission seeks to achieve. It seeks to widen the scope for Aboriginal self-management to encompass all of the programs undertaken within the portfolio agencies, and to deepen its real effectiveness by giving Aboriginal people at a regional and local level a far more specific responsibility to determine priorities and outcomes. It seeks also to establish the right mechanism for ministerial involvement which will genuinely uphold the principle of accountability to the broader Australian community (Commonwealth Parliamentary Debates, Vol. H of R 166: 1325-6, 11 April 1989).

The Minister for Aboriginal Affairs followed in similar vein arguing that while the essence of the ATSIC proposal had not changed, 'many modifications' had been made which dealt with 'the question of accountability'. He continued:

Changes to the Bill must be considered in the context of the basic principle of ATSIC that Aboriginal and Torres Strait Islander people should have greater control over matters affecting them. The question is one of balancing this principle with the principle of ministerial accountability for the correct and efficient use of public funds (Commonwealth Parliamentary Debates, Vol. H of R 166: 1334, 11 April 1989).

These modifications were still not enough to satisfy the Coalition, the Democrats and other critics of the ATSIC proposal. Over the next six months no less than 91 further amendments were made to the proposed legislation, many though certainly not all of which, had to do with public accountability. At the end of that process, the Coalition, despite having been significantly involved in the amendment process, still voted against the final ATSIC legislation (Commonwealth Parliamentary Debates, Vol. S 136: 2023-9, 17 October 1989). 
ATSIC has now been in operation some three and a half years, the first eight months with an interim board of five appointed Commissioners, and since December 1990 with 17 elected Commissioners drawn from the elected ASTIC Regional Councils, and three ministerially-appointed Commissioners including the Chairperson. In late 1992 a review of the operation of the ATSIC legislation was undertaken by senior administrators and ATSIC Commissioners (ATSIC 1993a). As a result, during 1993, some significant changes to the ATSIC legislation were passed through Parliament; the number of Regional Councils was reduced from 60 to 36, the positions of Commissioners and Regional Council Chairpersons became full-time and salaried and a number of other changes were made. The essence of the original ATSIC legislation, however, remained intact.

Elections for new ATSIC Regional Councils on new boundaries are being held on 4 December 1993 and will result in the subsequent election of a new set of Commissioners early in 1994. It is perhaps timely to ask, at the juncture of this second set of elections, whether ATSIC is succeeding in balancing, or reconciling, the two principles which Prime Minister Hawke identified as being the nub of its enabling legislation: public accountability and Aboriginal self-determination/self-management? This paper approaches that question by returning, in its first section, to the administrative inquiries of 1988-89 and what they found in their investigations of the alleged inadequacies in the existing administration of Aboriginal affairs. The second section looks briefly at the final ATSIC model which was passed by the Parliament in November 1989 and conceptualises it as a re-negotiated policy bargain. The third section identifies some of the criticisms that were still being made of the ATSIC model as it became a reality and during its early existence. It suggests that the path for ATSIC in attempting to reconcile these principles was clearly not going to be easy. The fourth section looks at ATSIC in practice over its first three and a half years and suggests that the organisation has indeed been trying quite hard to reconcile these two principles. The fifth section returns directly to the question of whether ATSIC is succeeding. It approaches the question in terms of different definitions of selfdetermination and different actors' perceptions. The paper's comments, in regard to this central question, are tentative and preliminary. They may, however, be useful in pointing the way for further research and analysis.

\section{The 1988-89 inquiries and public accountability}

Of the five inquiries into the existing administration of Aboriginal affairs in 1988-89, only three probably had a great effect on the subsequent fate of the ATSIC proposal with its emphasis on public accountability. These were the Department of Finance's inquiry into the financial management of the 
ADC, the Auditor-General's inquiry and the inquiry by the speciallyappointed senior public servant.

The Department of Finance's report began by noting that when the ADC was set up in 1980, it was the Fraser Government's intention to confer 'maximum independence and autonomy on the Commission' and that the powers given to the Minister for Aboriginal Affairs in the legislation were rather restricted:

For example, unlike most statutory authorities, there is no provision in the legislation for the Minister to approve the estimates (Department of Finance 1989b: 1).

It then went on to argue that:

potential problems inherent in such a structure have recently become apparent in Parliamentary considerations of the ADC's operations. Moreover, the provisions for independence in the ADC legislation now appear somewhat out of step with the Government's current policy guidelines for Commonwealth statutory authorities. These guidelines were tabled in parliament by the Minister for Finance and are aimed at enabling statutory authorities to operate independently but at the same time ensuring that they are publicly accountable and that their actions remain aligned with Government policy. As such, they are a necessary benchmark against which to review the interaction of the Minister and the Commission (Department of Finance 1989b: 1).

The Department of Finance concluded that the results of its review of the ADC's financial management demonstrated that:

there would be advantage in an increased amount of broad control/oversight being exercised by the Minister for Aboriginal Affairs over the policies and directions of the Commission's programs. Desirably, this should involve;

(i) increasing the amount of liaison between the Commission and the Minister for Aboriginal affairs (which has in the past been minimal);

(ii) the Minister approving the Commission's Estimates of receipts and expenditure and significant variations to those Estimates;

(iii) the Minister for Aboriginal Affairs endorsing the Commission's Corporate Plan; and

(iv) the Minister issuing broad policy guidelines in respect of the financial administration of the Commission's programs (Department of Finance 1989b: 2).

These were significant findings which clearly affected the Hawke Government's revised ATSIC proposal, particularly in relation to ministerial powers. Indeed at the end of his speech introducing the revised proposal, Minister Hand tabled directions to the ADC which were intended to ensure that 'defects' in its Act relating to ministerial and parliamentary oversight would be overcome and that, 'during its remaining life', it would operate 'on a similar basis to that envisaged for ATSIC and in a manner which properly reflects government priorities' (Commonwealth Parliamentary Debates, Vol. H of R 166: 1337, 11 April 1989). 
The second influential report was by the Auditor-General. It also criticised ADC's accountability to Parliament through the Minister, and in this respect, reinforced the Department of Finance's analysis. It suggested that many of the queries raised by Senators in Estimates Committee hearings and elsewhere in Parliament, were the result of 'inadequate information' in the ADC's annual reports, particularly in the area of enterprise grants and loans. In response to the ADC's defence that these were commercial matters which should remain confidential, audit expressed the view that:

its (ADC's) enterprise grants are in no sense commercial, that its enterprise loans are granted on concessionary terms and that both grants and loans are provided from public funds. The parliament and the public have a right to know who is receiving the funds, on what terms and for what kind of project.

Disclosure of this information would be helpful to avoid unnecessary speculation about the way the funds are applied. Disclosure, too, would help to improve approval procedures and administration within ADC. Government bodies are likely to feel their responsibilities more keenly when their decisions are public (Auditor-General 1989: 59).

The primary focus of the Auditor-General's 1989 report was not, however, on ADC's links with Parliament, but rather on administrative processes lower down the organisational hierarchies of DAA and ADC, particularly those relating to the provision of grants and loans to incorporated Aboriginal associations and individuals. The adequacy and public accountability of procedures in this subordinate aspect of Aboriginal affairs administration came under much scrutiny by the Auditor-General.

In relation to the ADC's funding of Aboriginal enterprise projects, the audit report found that there were 'serious defects' in almost all projects and that these resulted from 'defective approval procedures and management controls within the ADC'. Funds were often approved for purposes which the audit judged to be outside the statutory provision of 'enabling Aboriginals to engage in business enterprise' and without the ADC assessing 'the ability or fitness of identified Aboriginals to engage in the particular enterprise', as required in its Act. The failure to comply with this last statutory provision was seen as not readily excusable, since concern about this aspect of ADC's practices had been expressed in various parliamentary and other forums for some years. The ADC's enterprise program had, as the audit report saw it, 'occasionally been treated as a welfare program rather than a development program'; the audit report believed the ADC 'should be careful to distinguish' between these types of programs. The only consolation which the audit report offered in relation to the ADC's enterprise program was an admission that enterprise support is a program area in which 'successful outcomes' are difficult to achieve, since in 'most communities, success in business is something that many strive for but few achieve' (Auditor-General 1989: 8-10, 59). 
Nor did the DAA escape criticism from the Auditor-General in regard to its administration of grants and loans to Aboriginal organisations and individuals. Here, the Auditor-General took as a starting point an earlier audit report of 1986/87 which had identified 'weaknesses' in DAA's procedures relating to 'consultation, program development, compliance with grant conditions, assessment of performance' and 'administration by grant recipients including grant acquittals' (Auditor-General 1989: 74). The 1989 report found ongoing problems in all these areas. Consultation with communities over grants was still seen by the Auditor-General as unstructured and inadequate and DAA was seen as having made little progress with its promised solution of 'community plans'. Revised project evaluation forms had been introduced to improve assessment of project performance, but the audit report still found that the 'aims and objectives of some projects were defined too broadly for assessment using the performance measures required'. Failure to comply with grant conditions once a payment had been made was also still found to be widespread, and the DAA's actions to 'overcome deficiencies' in this area were generally judged to have been 'unsuccessful'. Non-acquittal of grants at the conclusion of the grant receiving process was also still judged to be a problem, although on this count the audit report did note 'substantial progress' since 1987 (Auditor-General 1989: 101-3).

The third influential inquiry by the specially-appointed senior public servant was also concerned with decision-making processes within the $\mathrm{ADC}$ and the DAA relating to the provision of grants to Aboriginal organisations, and in some instances also the subsequent actions of executive officers of those organisations. It involved a number of allegations of misconduct in these decision-making processes. Three of the matters most closely scrutinised involved Charles Perkins in his former role as Secretary of the DAA. These matters raised issues about the adequacy of grant assessment procedures in instances where grant applications had come direct to Perkins and DAA central office, rather than through the normal regional office network and also the possibility of conflicts of public and private interest in Perkins' participation in decisionmaking processes. Though none of the allegations against Perkins, and only one of the other ten allegations investigated was substantiated, the specially-appointed inquirer did express some disquiet in relation to several of the matters. He recommended that grant assessment procedures in the DAA should be changed, thereby reinforcing the finding of the AuditorGeneral's report. He also recommended that, although disciplinary action against Perkins should not be taken, the findings of his inquiry should be drawn to Perkins' attention (Department of Prime Minister and Cabinet 1989: 61-2). This last finding put the issue of conflict of interest squarely on the agenda of debate for the revised ATSIC legislation. 


\section{The final ATSIC model: a renegotiated policy bargain}

The effects of these criticisms of the existing administration of Aboriginal affairs on the final ATSIC legislation which emerged from Parliament in November 1989 were plain to see. In many ways what emerged was a new model, or significantly changed set of rules, for Aboriginal affairs administration; a renegotiated 'policy bargain' to use Levi's (1993) language. Aboriginal self-management would, as Prime Minister Hawke had suggested, be widened and deepened. Executive control over almost all Commonwealth Aboriginal affairs portfolio expenditure would be handed over to a largely-elected body of Aboriginal Commissioners. There was also provision for the devolution of grant funding decision-making within ATSIC to the level of elected Regional Councils, at least in an advisory capacity. All this, however, would come at a price. The price was more stringent accountability for the expenditure of public funds. There would be greater ministerial oversight of the organisation's estimates and some other possibilities for ministerial intervention, albeit largely as powers of last resort. There would also be clearer specifications of procedures to be followed by ATSIC in assessment and administration of grants and loans, and clear statutory delineations of the purposes for which grants and loans could be made. This was the renegotiated policy bargain.

Public accountability aspects of this renegotiated bargain could be clearly seen in many sections of the final ATSIC legislation: $\mathrm{s} .12$ providing for 'general directions' to be given to the Commission by the Minister provided they are 'laid before the Parliament'; s.20 providing that grants and loans made by the Commission may be repayable where conditions are breached; s.22 stating that grants and loans are not to be made without a written application and assessment; s.24 stating that loan, grant and other Commission documents are to set out the legislative authority under which they are made; s.37 and s.38 relating to disclosure of interests by Commissioners; s.61 stating that monies of the Commission shall not be spent other than 'in accordance with estimates of expenditure approved by the Minister'; s.63 and s.64 specifying how draft budgets are to be prepared and submitted to the Minister for approval; s.65 allowing for Ministerial alteration of draft budgets provided these are explained in a statement to the Parliament; s.66 stating that money held by the Commission shall only be applied 'in payment or discharge of the cost, expenses and other obligations incurred by the Commission in the performance of its functions or the exercise of its powers'; s.69 and s.70 placing strict limits on the Commission's ability to borrow money; s.72 imposing stringent annual reporting procedures on the Commission; s.74 providing that the Minister can give 'written directions' to the Commission regarding the administration of its finances; s.75 and s.76 establishing an Office of Evaluation and Audit (OEA) within the Commission to regularly evaluate and audit its operations and to report direct to the Minister and the 
Commission through a Director, who shall be appointed by the Minister after consultation with the Commission (Act No. 150 of 1989).

\section{The renegotiated policy bargain: would it work?}

Not all were convinced that this new policy bargain would work. As noted above, the Coalition parties maintained their opposition to the ATSIC legislation in the Parliament to the last, despite becoming substantially involved in the amendment process (Commonwealth Parliamentary Debates, Vol S. 136: 2023, 17 October 1989). They had, in the course of the debate, expressed the fundamental fear that the government was creating a separate Aboriginal Parliament which would strike at the very unity of the Australian nation (Commonwealth Parliamentary Debates, Vol. H of R 166:1332, 11 April 1989). Somewhat less apocalyptically, they had also worried that the 'fusion' of representative and executive roles within ATSIC would not overcome the problems of past Aboriginal affairs administration but rather would lead to 'confusion' and even 'greater chaos and shambles' in the future, as the new organisation attempted to 'serve two masters' (Commonwealth Parliamentary Debates, Vol. H of R 166:1340, 11 April 1989). ${ }^{2}$

On a somewhat different tack, the Royal Commission into Aboriginal Deaths in Custody, writing during the early months of ATSIC's existence, seemed to suggest that the new Commission probably still did not go far enough towards Aboriginal self-determination. It noted that ATSIC only controlled a little over one-half of Commonwealth Aboriginal assistance expenditure, while the rest continued to be administered by Commonwealth departments with 'none of the trappings of selfdetermination which the ATSIC structure provides'. The Royal Commission also seemed to suggest that ATSIC did not go far enough down the self-determination path because:

staff remain Commonwealth public servants whose primary accountability, in the performance of duties and in the interpretation of policy guidelines, is to the Chief Executive Officer, a full-time public servant appointed by the Minister (Commonwealth of Australia 1991b: 8).

Elsewhere the Royal Commission also noted, that while Aboriginal people 'rightly demand their citizens' rights', they also 'frequently, suggest that their entitlement ... is different to that of other Australians':

Not only do Aboriginal people feel, quite justifiably, that no amount of equality now in the delivery of citizens' entitlements will make up for the failure to deliver such entitlements over the past century or more. They also feel that what, to non-Aboriginal people, is a citizens' right (which is subject to assessment, monitoring and may be taken away if the citizen fails to meet administrative and other criteria) should be available for them on a basis rather like that which 
might apply if compensation payments were made for past injustices. Given that sense of injustice, many Aboriginal people regard it as an added insult that payments made, either directly or through Aboriginal organisations, to meet basic needs should be subject to the minute and suspicious scrutiny which accompanies such payments. At this level, Aboriginal people would see the whole process of delivery of such services as being one of further control of their lives and not one which offers autonomy (Commonwealth of Australia 1991a: 525-6).

If this attitude among Aboriginal people was, in fact, as widespread as the Royal Commission suggested then the prospect of ATSIC getting Aboriginal people to comply with more stringent public accountability requirements, might indeed have seemed slim. Elsewhere, however, in a somewhat contrary vein, the Royal Commission noted that:

It is no diminution of Aboriginal self-management to insist that monies expended be accounted for to the funding agency (Commonwealth of Australia 1991b: 14).

In the end, the Royal Commission's attitude to ATSIC, and the new policy bargain which it represented, seemed to be one of ambivalence, of wanting to wait and see. ${ }^{3}$ ATSIC, the Royal Commission said, was an 'important new feature of Australian society' which, in giving Aborigines 'executive rather than advisory powers over Commonwealth programs dedicated to their welfare' answered 'a need articulated by Aboriginal leaders and nonAboriginal advisers since 1974'. However, the Royal Commission also catalogued widespread Aboriginal pessimism and criticism about ATSIC, some of which it argued 'could prove valid' (Commonwealth of Australia 1991b: 7-9).

Perhaps of greater foreboding for the renegotiated policy bargain than the Royal Commission's comments, were those made about the same time by former DAA Secretary and one-time participant in the early consultations relating to ATSIC, Charles Perkins. In 1991 he attacked ATSIC as 'a creation of white politicians and bureaucrats' and suggested that it be reorganised so that:

All appropriations to the commission ... and other Aboriginal category-funding should be by special allocation in the federal budget and go directly to a nongovernment "capital fund" and be administered by ATSIC. This appropriation should not be regarded as public funds once allocated and should come under the direct control of the commission and its elected Aboriginal and Torres Strait Islander Commissioners to be dealt with as they see fit (Perkins 1992: 228-9).

Clearly, the path for ATSIC in trying to reconcile public accountability and Aboriginal self-determination/self-management was not going to be easy. It had critics and pessimists on all sides from the outset. However, in the same forum in 1991 in which Perkins attacked ATSIC, the Commission's Chairperson Lois O'Donoghue, perhaps predictably, adamantly defended it. 
She saw ATSIC as 'a truly Aboriginal body' which would 'stand or fall on its use of public funds and on the effectiveness of its programs' (O'Donoghue 1992: 221). O'Donoghue, for one, clearly wanted to give the renegotiated policy bargain a chance.

\section{ATSIC in practice}

ATSIC in practice has proven to be a most interesting experiment. As might be expected, there was some considerable tension at first between the administrative arm, inherited from DAA and ADC, and the representative arm. The relationship, at least at the national level if not so much at the regional level, seemed however, to settle down surprisingly quickly. One reason for this, was that the Aboriginal Commissioners showed themselves, from early on, to be quite receptive to the public accountability concerns expressed at the time of the debates over ATSIC's formation and enabling legislation. Complementing this was an apparent willingness, on the part of the administrators, to hand over decision-making to the Commissioners in the name of self-determination/self-management.

One early example of both these tendencies was a decision, taken by the Commissioners in late 1990 , to stop quarterly cash releases to funded bodies that had not acquitted previous grants more than one quarter after they were required to do so. ${ }^{4}$ This was something many Aboriginal affairs administrators would have liked to have done in previous years, in an attempt to meet the growing public accountability pressures on them from Parliament and elsewhere. They, however, had felt unable to do so because of anticipated cries about cutting off funds from needy organisations. Now the Aboriginal Commissioners were taking this stand for the administrators and showing themselves, in the process, to be quite accepting of public accountability concerns in their decision-making.

Grant acquittal is, in many ways, a fairly formal and late step in the grant administration process, which simply demonstrates that moneys granted have been spent for their intended purposes. The significance of this one decision should not therefore be overstated. However, what it seems to have initiated has been an ongoing review process of all grant administration processes within ATSIC, from application and assessment, through agreement with the funded body and funds release, to outcome monitoring and acquittal. Some of this review of procedures was necessary simply to fulfil the requirements of the ATSIC legislation. However, some of it has gone further; it has been an attempt by the new organisation to quite significantly improve the grants administration processes it inherited from DAA and ADC, both for its own internal purposes and in anticipation of close scrutiny from bodies such as the Parliament and the AuditorGeneral. Interestingly, not all of the changes that have been and are still 
being made should necessarily be seen as 'tightening up' on grant administration. One trend has been to attempt to distinguish between different levels and types of grants made by the organisation and to adjust procedures accordingly. Hence some procedures for small grants are probably becoming less onerous for applicants and recipients, while those for larger grants may be somewhat more stringent.

One effect of this ongoing review of grant administration processes, and the Commissioners' support for it, has been to facilitate the relationships between the representative and the administrative arms of ATSIC, at least at the national level. Senior national administrators and the Minister, who were the ones likely to be required to defend the organisation in various parliamentary and administrative forums, have generally felt they have had the Commissioners' support and appreciation of the degree of scrutiny over public accountability that they were likely to face.

Another interesting and important aspect of ATSIC in practice over the last three years has been its apparent willingness to examine and review the substance of what it does, both in terms of programs and their approaches. This is considerably different from past Aboriginal affairs administration, which can be characterised as frequently adding new sub-program elements, but seldom greatly changing old ones. Part of this change of organisational ethos could again be attributed to the ATSIC legislation and the new activities, such as corporate planning, regional planning and OEA reviews, which it requires ATSIC to undertake. But the review process goes further; it would seem to suggest an organisation which is reasonably willing to look at and review what it does, both in the pursuit of program effectiveness and of public accountability in the somewhat broader more substantive sense.

The contribution of the OEA, in establishing this ethos of review and the potential for program change within ATSIC, is an interesting question. As with any internal auditor, there has been considerable antipathy towards the OEA and its work within ATSIC. However, as suggested in a case study of an evaluation of ATSIC's Enterprise Development program, recounted by a former OEA Director, initial resistance and hostility to the Office's work should not be equated with ineffectiveness. He argues that this particular evaluation was 'highly successful' in that it pushed program administrators to 'ask some hard questions' (Dillon 1992: 98-100). The process which it started has now resulted in some significant program changes, such as an attempt to distinguish more clearly between commercial and socially-based enterprises, as recommended over the years by the Auditor-General, and some administrative restructuring of assessment procedures away from regional offices to state offices of ATSIC in order to enhance the professionalism of business viability assessments (see ATSIC 1993b: 43). Interestingly, in the 1993 amendments to the ATSIC legislation, the role of 
the OEA was considerably strengthened. Its evaluation and audit activities were extended to cover ATSIC-funded bodies and Regional Councils, as well as the ATSIC administration.

Another area of considerable change in ATSIC's program structure and practice over the past three and a half years has been in the amount of expenditure allocated on the advice of the elected Regional Councils. This has increased to around $\$ 230$ million, or about a quarter of the ATSIC budget in the 1993-94 financial year, starting from zero three years previously and rising to $\$ 155$ million in 1992-93. This devolution of decision-making in the representative arm would appear to be what Prime Minister Hawke had in mind when he talked of the 'deepening', as well as the 'broadening', of Aboriginal self-management through ATSIC; and it certainly is occurring quite rapidly. The process has, however, not always proceeded smoothly, as the relationship between elected Aboriginal councillors and administrators at the regional level of ATSIC has not yet been as fully worked through as that between Commissioners and administrators at the national level.

Until 1993 the powers of Regional Councils in relation to ATSIC expenditure were advisory. Regional administrators were, as a consequence, somewhat unclear as to their strength. The 1993 legislative amendments, however, allow the delegation of Commission powers to Regional Councils. They clearly increase the power and authority of the Regional Councils, both in recognition of the degree of devolution of decision-making that has already occurred and in anticipation of further devolution in the future. It is interesting to recall, in this regard, that both Regional Council Chairpersons and Commissioners have been made fulltime paid positions by the 1993 amendments. This would seem to suggest that both roles have proved more onerous and more extensively involved in ATSIC's decision-making processes than anticipated at the outset. It is also of interest to note, however, that the move to delegate Commission powers to Regional Councils has been accompanied by amendments which extend the powers of the OEA to cover Regional Councils and strengthen the disclosure of interest provisions relating to Regional Councillors. It would appear that with increased decision-making powers for the Regional Councils is to come increased public accountability measures. This is entirely consistent with the renegotiated policy bargain of 1989 .

The powers of the Minister have also proved an interesting issue for ATSIC. In line with the spirit of self-determination/self-management, Minister Tickner has been keen to point out that decisions are generally made by the Commission and not, in most instances, by him. As well as overseeing the budget process, two of the powers that the Minister does have are to appoint the Chairperson of the Commission and to direct the OEA to undertake audit and evaluation tasks. Where public accountability 
has appeared to be at issue, this latter power has sometimes proved useful; as in 1990 when the Minister directed OEA to investigate grant acquittals (Office of Evaluation and Audit 1991). In more recent times the senior administrators and Commissioners reviewing the ATSIC legislation suggested that these two ministerial powers should be abolished, because they were 'contrary' to the 'principles' of self-determination and selfmanagement embodied in the Act (ATSIC 1993a: 14, 22). However, the Minister was unwilling to accept these proposals and did not act on them in the 1993 legislative amendment processes. Clearly the Minister thought that the powers he had in relation to ATSIC over the appointment of the Chairperson and the direction of OEA were essential to public accountability and were worth retaining.

\section{Is ATSIC succeeding? definitions and perceptions}

That brings us back to the central question: is ATSIC succeeding in reconciling public accountability and Aboriginal self-determination/selfmanagement? Much of what has been said in the previous section would seem to suggest that ATSIC has certainly been trying hard to reconcile these two principles over the first three and a half years of its existence. Whether these efforts are meeting with success, however, may depend to some extent on ones perspective, how one perceives ATSIC and how one defines these central terms in Aboriginal policy.

The term 'self-determination', for example, as the Royal Commission into Aboriginal Deaths in Custody noted, is subject to extremely varied interpretations (Commonwealth of Australia 1991a: 503-9). In international law and politics, this term is often associated with the right of a people to determine their own status within or as a separate nation state. When applied as a central policy term to a small, dispersed indigenous minority within an existing nation state, who have very little ability to greatly alter that encompassing state structure, the term is somewhat provocative. If one wishes to insist on the international law meaning, self-determination for Aboriginal Australians is probably not only unachievable but also ultimately irreconcilable with notions of public accountability to a larger nation state. However, as Brennan (1991: 43-52) points out, in the context of indigenous Australians, the term is more one of 'political art' than 'legal precision'. If one is willing to accept what Brennan refers to as selfdetermination in the 'domestic sense', which includes some form of Aboriginal participation in important decision-making processes within the existing nation state, then the two principles may no longer seem quite so irreconcilable. Even within this 'domestic sense', however, there may still be problems. As suggested above in the Royal Commission's and Perkins' 1991 comments, it is quite possible to adopt the view that selfdetermination means that Aboriginal people are not accountable for 
moneys devoted to their assistance precisely because those moneys are to be seen as 'compensation' for past dispossession and injustices. Clearly, to reconcile public accountability and Aboriginal self-determination, even in principle, a fairly pragmatic, and in some senses rather limited view of the latter term must be taken. That pragmatic view is likely to emphasise Aboriginal participation in government decision-making processes that affect their lives; and that of course is ATSIC's claim to being an embodiment of Aboriginal self-determination.

Within this pragmatic and limited domestic sense of self-determination, it is still probable that different actors will disagree in their assessment of the degree to which ATSIC is, in practice, reconciling Aboriginal selfdetermination and public accountability. Recent research by an Aboriginal middle-level manager in ATSIC, Russell Taylor, suggests that his bureaucratic superiors think they have made a reasonable start in reconciling these two principles. Those Taylor interviewed definitely did not see the two principles as 'mutually exclusive' and, though they thought the 'optimum balance' was still emerging, most also thought that a 'reasonable balance' had already begun to be struck (Taylor 1992: 93-102). However, senior bureaucrats are only one set of stakeholders in ATSIC, and it is equally important to inquire of the perceptions of others, such as the Commissioners, Regional Councillors, Aboriginal people outside the organisation, the Minister, Parliament and the Auditor-General. Systematically identifying and interpreting the perceptions of all these stakeholders on this question is beyond the scope of this paper. However, some preliminary comments and observations can be made and may be useful in directing further research and analysis.

Parliamentarians, particularly of the Coalition persuasion, seem no less intent on rigorously questioning the Government over the generalities and specifics of Aboriginal affairs administration in 1993 than they did five years ago (see, for example, Commonwealth Parliamentary Debates, Senate Estimates Committee A, 20 September 93). The results of this Parliamentary probing, however, have not at this stage led to any allegations which have created a sense of unease or crisis in Aboriginal affairs administration, as they did in 1988. In a somewhat contrary vein, it is interesting to note that the Coalition has now withdrawn its official opposition to ATSIC and would have retained the organisation had it been elected to government at the 1993 federal election (Wooldridge 1992).

The Auditor-General has also continued to rigorously examine Aboriginal affairs administration in the years since ATSIC's establishment. Though reports still frequently find problems in areas such as grant administration, community planning and coordination of programs with other levels of government (see, for example, Auditor-General 1992; Auditor-General 1993), the Auditor-General's office has thus far been willing to support 
ATSIC and to encourage its efforts to improve the quality of its administration. For example, at the 1993 Senate Estimates Committee hearings the senior representative of the audit office stated:

In our work over the last two years we have seen a real intent on the part of ATSIC to improve the quality of its procedures for controlling grants. ... A number of changes are being put in place which we think are in the right direction. We think that the main items on the agenda that ATSIC will be facing in the coming period will be, firstly, to lock down those new change arrangements that it is introducing - that is, to finalise the implementation of the procedures - and, secondly, and in the long run perhaps the most difficult aspect, to enforce them and ensure that they are applied in practice (Commonwealth Parliamentary Debates, Senate Estimates Committee A, 20 September 1993: A150).

While the Auditor-General clearly supported ATSIC, this support was by no means unconditional, or guaranteed to continue in the future.

The Minister's attitude to ATSIC's balancing of Aboriginal selfdetermination/self-management and public accountability, would seem to be summed up by the recent legislative amendment process. While the Minister clearly backed further devolution of decision-making within ATSIC to the Regional Councils, he also maintained and even strengthened the public accountability provisions of the ATSIC legislation. As noted above, the role of the OEA was strengthened and so too were the disclosure of interest provisions. The legislative amendments also maintained, in the face of challenge, existing ministerial powers. Clearly, public accountability concerns are as strong in 1993 for Minister Tickner as they were for his predecessor in 1988-89.

Aboriginal perceptions of ATSIC's success in reconciling public accountability and self-determination are probably even more diverse and difficult to discem than those of parliamentary and governmental actors. Yet they are equally important in determining the likelihood of ATSIC's longer-term success. Though the present set of Commissioners seems to have recognised and pragmatically accepted the current strength of concerns for public accountability of funds expended through ATSIC, there is no guarantee that other Aborigines have also. Regional Councillors and the many other Aboriginal people not directly associated with ATSIC's structure may have quite different perceptions. Even those of the outgoing Commissioners could be more deeply probed to see how principled, or simply pragmatic, their concern for public accountability has been.

A sampling of ATSIC Regional Council reports for 1992 would seem to suggest that there was, at that stage, still a fairly wide range of attitudes even among the elected representatives. Some Regional Councillors praised ATSIC highly, while others continued to damn it. One Council Chairperson argued that concerns about whether 'regional staff would dominate or attempt to dictate' to the Council were 'no longer an issue of 
concern' and that now 'we are making our own decisions' (Impiyara Regional Council 1992). Another, however, in contrast, argued that ATSIC was still 'a white dictatorship' reproducing 'old regimes so firmly entrenched in past organisations' under a 'change of name' (Gattang Regional Council 1992). With such diversity of views among Regional Councillors as late as 1992 , it is probably also to be expected that the larger Aboriginal population is still also greatly divided in its views.

In light of this continuing diversity of Aboriginal views, the December 1993 ATSIC Regional Council elections may well turn out to be a litmus test of ATSIC's longer-term acceptance, or otherwise, by Aboriginal people. At the time of the 1990 elections, ATSIC was still very much unknown to many Aborigines. Participation in that first election indicated Aboriginal people's ambivalence. A figure of 36 per cent voter turnout was subsequently quoted by Perkins in order to cast doubt on ATSIC's 'mandate' (Perkins 1992: 228). Whether turnout and interest are higher in 1993 will be crucial to observe. If they are, then this may indicate that increasing numbers of Aboriginal people are judging that ATSIC's particular balance of self-determination and public accountability is worthwhile. If not, then the long-term success of ATSIC may be thrown more into question.

The December 1993 ATSIC Regional Council elections will be followed, in early 1994, by an election of new ATSIC Commissioners. This in itself will be a major test for the organisation. It will be of interest to see whether the new Commissioners are as receptive to concerns for public accountability as the outgoing Commissioners have been. Some attempt to pass on knowledge and attitudes has clearly been made by the current members of ATSIC in drawing up The ATSIC Protocol, a descriptive document of the roles and relationships between the component parts of ATSIC as they are presently understood (ATSIC 1993c). This, however, is no guarantee that future occupants of these roles will necessarily accept or agree with past interpretations and practices. The possible absence from the Commission in the near future of the present and original appointed Chairperson, Lois O'Donoghue, may also be significant. She has done much to set the tone of the Commission, emphasising probity in decisionmaking and showing a sympathetic attitude towards demands for public accountability, as well as those for greater Aboriginal self-determination. Whether a new Chairperson will keep this balancing act going is interesting to contemplate.

\section{Concluding comment}

Perhaps the most substantial conclusion that can be reached about ATSIC's attempts to reconcile public accountability and Aboriginal selfdetermination/self-management at this stage is that it is too early to make a 
judgement on longer-term prospects of success. A reasonable start has been made, and there is certainly no great sense of failure, crisis or loss of morale in ATSIC, as there was in the latter days of both the NAC and the ADC. However, longer-term success in ATSIC's delicate balancing act is not as yet assured. That would seem to depend on the perceptions and attitudes of the various stakeholders in ATSIC, on both the governmental and Aboriginal sides, and how these develop over the next few years.

\section{Notes}

1. The terms Aborigines and Aboriginal are used throughout to refer to all indigenous Australians, including Torres Strait Islanders. The term selfdetermination was first used in relation to Aboriginal policy by the Whitlam government. The Fraser government used the term self-management, partly to distinguish itself from the Whitlam years, see Sanders (1982). The Hawke government, however, used the two terms, with any clear distinction in the contexts of their usage being difficult to discern. Because this paper primarily concerns the Hawke years and beyond, I have used both terms and have tried to respect the usage made at the time by those to whom I am referring.

2. On the general problem of serving two masters in Aboriginal affairs administration, and also for some useful reflections on the early ATSIC debates and the Perkins resignation, see Wettenhall (1989).

3. On the Royal Commission's attitude to ATSIC more generally, see Rowse (1992).

4. A copy of this Commission decision no. 322 can be found at Attachment E in Office of Evaluation and Audit 1991. Perhaps it should be noted in passing that when this decision was originally taken the Commission was still totally comprised of appointed members. The policy has, however, been maintained during the period of predominantly elected Commissioners.

\section{References}

Aboriginal and Torres Strait Islander Commission 1993a. Review of the Operation of the Aboriginal and Torres Strait Islander Commission Act 1989, Australian Government Publishing Service, Canberra.

Aboriginal and Torres Strait Islander Commission 1993b. Annual Report 1991-92, Australian Government Publishing Service, Canberra.

Aboriginal and Torres Strait Islander Commission (ATSIC) 1993c. The ATSIC Protocol, Office of Public Affairs for the Strategic Development Unit, ATSIC, Canberra.

Auditor-General 1989. Special Audit Report: the Aboriginal Development Commission and the Department of Aboriginal Affairs, Australian Government Publishing Service, Canberra.

Auditor-General 1992. Efficiency Audit: Aboriginal and Torres Strait Islander Commission Regional Administration, Audit Report No. 15 1992-93, Australian Government Publishing Service, Canberra. 
Auditor-General 1993. Project Audit: Aboriginal and Torres Strait Islander Commission Community Infrastructure, Audit Report No. 36 1992-93, Australian Government Publishing Service, Canberra.

Brennan, F. 1991. Sharing the Country: The Case for an Agreement Between Black and White Australians, Penguin, Ringwood, Victoria.

Commonwealth of Australia 1991a. Royal Commission into Aboriginal Deaths in Custody: National Report, vol. 2, (Commissioner E. Johnston), Australian Government Publishing Service, Canberra.

Commonwealth of Australia 1991b. Royal Commission into Aboriginal Deaths in Custody: National Report, vol. 4, (Commissioner E. Johnston), Australian Government Publishing Service, Canberra.

Coombs, H.C. 1984. The Role of the National Aboriginal Conference, Australian Government Publishing Service, Canberra.

Department of Finance 1989a. Report on Certain Staff Classification Matters in the Department of Aboriginal Affairs, Australian Government Publishing Service, Canberra.

Department of Finance 1989b. Report on the Financial Management of the Aboriginal Development Commission, Australian Government Publishing Service, Canberra.

Department of Prime Minister and Cabinet 1989. Inquiry by Mr A.C.C. Menzies into Allegations as to the Administration of Aboriginal Affairs, Australian Government Publishing Service, Canberra.

Dillon, M.C. 1992. 'Program evaluation and monitoring in Aboriginal and Torres Strait Islander affairs: a strategic overview', in C. O'Faircheallaigh and B. Ryan (eds) Program Evaluation and Performance Monitoring: An Australian Perspective, Macmillan, Melbourne.

Gattang Regional Council 1992. 1992 Annual Report, Aboriginal and Torres Strait Islander Commission, Wyong.

Hiatt, L. 1976. Australian Committee of Inquiry into the Role of the National Aboriginal Consultative Committee, Australian Government Publishing Service, Canberra.

House of Representatives Standing Committee on Expenditure 1984. Inquiry into the Aboriginal Development Commission, Australian Government Publishing Service, Canberra.

Impiyara Regional Council 1992. 1991/92 Annual Report, Aboriginal and Torres Strait Islander Commission, Alice Springs.

Levi, M. 1993. 'The construction of consent', Administration, Compliance and Governability Program: Working Paper No. 10, Research School of Social Sciences, Australian National University, Canberra.

O'Donoghue, L. 1986. An Aboriginal and Islander Consultative Organisation, Australian Government Publishing Service, Canberra.

O'Donoghue, L. 1992. 'Ending the despair', Australian Journal of Public Administration, 51 (2): 214-22. 
Office of Evaluation and Audit 1991. Evaluation of Unacquitted Grants, Aboriginal and Torres Strait Islander Commission, Canberra.

Perkins, C. 1992. 'Aboriginal Australia and public administration', Australian Journal of Public Administration, 51 (2): 223-33.

Public Service Commission 1989. Reports on Allegations About Personnel Management in the Department of Aboriginal Affairs, Australian Government Publishing Service, Canberra.

Rowse, T. 1992. 'The Royal Commission, ATSIC and self-determination: a review of the Royal Commission into Aboriginal Deaths in Custody', Australian Journal of Social Issues, 27 (3): 153-72.

Sanders, W. 1982. 'From self-determination to self-management', in P. Loveday (ed.) Service Delivery to Remote Communities, North Australia Research Unit, Australian National University, Darwin.

Senate Select Committee on the Administration of Aboriginal Affairs 1989. Administration of Aboriginal Affairs, Australian Government Publishing Service, Canberra.

Taylor, R. 1992. 'ATSIC: a perceived dichotomy', unpublished Master of Business Administration project, University of Technology, Sydney.

Wettenhall, R. 1989. 'Aboriginal administration: should we bend the rules?', Current Affairs Bulletin, 4-11 February 1989.

Wooldridge, M. 1992. 'ATSIC - the way forward', Discussion Paper of Proposals for the Next Coalition Government, Shadow Minister for Aboriginal Affairs, 26 June 1992. 




\section{CENTRE FOR ABORIGINAL ECONOMIC POLICY RESEARCH (CAEPR) RECENT DISCUSSION PAPERS}

19/1992 Estimating the reliance of Aboriginal Australians on welfare: some policy implications, J.C. Altman and D.E. Smith.

20/1992 Establishing trends in ATSIC regional council populations using census data: a cautionary note, J.C. Altman and K.H.W. Gaminiratne.

21/1992 Do fluctuations in the Australian macroeconomy influence Aboriginal employment status?, J.C. Altman and A.E. Daly.

22/1992 Industry segregation among employed Aborigines and Torres Strait Islanders, J. Taylor.

23/1992 The evaluation of labour market programs: some issues for Aboriginal policy formulation from experience in the United States, A.E. Daly.

24/1992 First counts, 1991 Census: a comment on Aboriginal and Torres Strait Islander population growth, K.H.W. Gaminiratne.

25/1992 Patterns and trends in the spatial diffusion of the Torres Strait Islander population, J. Taylor and W.S. Arthur.

26/1992 Aborigines, tourism and sustainable development, J.C. Altman and J. Finlayson.

27/1992 Political spoils or political largesse? Regional development in northern Quebec, Canada and Australia's Northern Territory, C. Scott.

28/1992 Survey or census? Estimation of Aboriginal and Torres Strait Islander housing need in large urban areas, J. Taylor.

29/1992 An analysis of the Aboriginal component of Commonwealth fiscal flows to the Northern Territory, D.E. Smith.

30/1992 Estimating Northern Territory Government program expenditure for Aboriginal people: problems and implications, D.E. Smith.

31/1992 Estimating Aboriginal and Torres Strait Islander fertility from census data, K.W.H. Gaminiratne.

32/1992 The determinants of Aboriginal employment income, A.E. Daly.

33/1992 Occupational segregation: a comparison between employed Aborigines, Torres Strait Islanders and other Australians, J. Taylor.

34/1992 Aboriginal population change in remote Australia, 1986-91: data issues, J. Taylor.

35/1992 A comparison of the socioeconomic characteristics of Aboriginal and Torres Strait Islander people, J. Taylor and K.H.W. Gaminiratne.

36/1992 The CDEP scheme: a census-based analysis of the labour market status of participants in 1986, J.C. Altman and A.E. Daly. 
37/1993 Indigenous Australians in the National Tourism Strategy: impact, sustainability and policy issues, J.C. Altman.

38/1993 Education and employment for young Aborigines, A.E. Daly.

39/1993 Self-employment amongst Aboriginal people, A.E. Daly.

40/1993 Aboriginal socioeconomic change in the Northern Territory, 1986-91, J. Taylor.

41/1993 ATSIC's mechanisms for resource allocation: current policy and practice, D.E. Smith.

42/1993 The fiscal equalisation model: options for ATSIC's future funding policy and practice, D.E. Smith,

43/1993 The position of older Aboriginal people in the labour market, A.E. Daly.

44/1993 Determining the labour force status of Aboriginal people using a multinomial logit model, A.E. Daly, B. Allen, L. Aufflick, E. Bosworth, and M. Caruso.

45/1993 Indigenous Australians and the labour market: issues for the union movement in the 1990 s, J.C. Altman and A.E. Hawke.

46/1993 Rethinking the fundamentals of social policy towards indigenous Australians: block grants, mainstreaming and the multiplicity of agencies and programs, W. Sanders.

47/1993 Compensating indigenous Australian 'losers': a community-oriented approach from the Aboriginal social policy arena, J.C. Altman and D.E. Smith.

48/1993 Work and welfare for indigenous Australians, A.E. Daly and A.E. Hawke.

49/1993 Change in Aboriginal and Torres Strait Islander population distribution, 1986-91, K.H.W. Gaminiratne.

50/1993 Education and employment for young indigenous Australians, 1986 to 1991, A.E. Daly.

51/1993 Reconciling public accountability and Aboriginal self-determination/selfmanagement: is ATSIC succeeding?, W. Sanders.

52/1993 Indicative projections of the Aboriginal and Torres Strait Islander population to 2011, A. Gray and K.H.W. Gaminiratne.

53/1993 Employment implications of the growth of the indigenous Australian working-age population to 2001, J.C. Altman and K.H.W. Gaminiratne.

54/1993 The rise and rise of the CDEP scheme: an Aboriginal 'workfare' program in times of persistent unemployment, W. Sanders.

For information on earlier CAEPR Discussion Papers contact Nicky Lumb, Centre for Aboriginal Economic Policy Research, Faculty of Arts, Australian National University, Canberra ACT 0200. Ph (06) 2490587 Fax (06) 2492789. 

